\title{
Swallowing Disorders: Dysphagia
}

\author{
*Raniya Naanai \\ Speech language pathologist At Noor Center for Physiotherapy \& Rehabilitation, Casablanca, Africa
}

Submission: July 31, 2017; Published: August 03, 2017

*Corresponding author: Raniya Naanai, Speech language pathologist At Noor Center for Physiotherapy \& Rehabilitation, Casablanca, Morocco, Africa, Email: rania.nanaani@gmail.com

\section{Mini Review}

Dysphagia is a disorder of movement that causes either discomfort or difficulty swallowing liquid foods such as solids. Dysphagia is often associated with pathology, but not necessarily. Speech therapist treats dysphagia through rehabilitation.

a) Definition of dysphagia

b) Dysphagia is a symptom that disrupts the swallowing process

c) What is swallowing?

When we ingest food, they are chewed and then directed to the stomach without it implying the airways. It's swallowing. This mechanism, when disturbed, can initiate the functional and vital prognosis of the person who is affected. This is called dysphagia or swallowing disorders (TD).

a) Dysphagia: a variable symptom

b) Dysphagia can vary from simple discomfort to food passage to food blockade of solids; in this case it is a complete dysphagia.

c) It can also prevent the passage of liquids: it is called aphagia.

d) Dysphagia can be permanent, intermittent, and sometimes even allow easier passage to solid than liquid foods.

\section{Causes of Dysphagia}

The causes of dysphagia can be:
i. Mechanical;
ii. Neurological;
iii. Or muscular.

The causes are therefore numerous, we shall cite but a few (Table 1).
Table 1.

\begin{tabular}{|c|c|c|}
\hline \multicolumn{3}{|c|}{ Causes of Dysphagia } \\
\hline \multirow{3}{*}{ Anomaly at birth } & \multicolumn{2}{|c|}{$\begin{array}{l}\text { a) Anomalies of the palate (a hole in } \\
\text { the palate at birth complicates breastfeeding } \\
\text { because the infant cannot suck appropriately). }\end{array}$} \\
\hline & \multicolumn{2}{|c|}{$\begin{array}{l}\text { Anomalies of the swallowing } \\
\text { mechanism. }\end{array}$} \\
\hline & \multicolumn{2}{|c|}{$\begin{array}{l}\text { Angioma: benign malformation } \\
\text { of the vessels causing a deformation of their } \\
\text { shape and structure }\end{array}$} \\
\hline \multirow{4}{*}{ Lesion } & \multicolumn{2}{|c|}{$\begin{array}{l}\text { To the esophagus (ulcer or Crohn's } \\
\text { disease); }\end{array}$} \\
\hline & b) & At the larynx; \\
\hline & c) & In the head ; \\
\hline & d) & In the neck \\
\hline \multirow{6}{*}{ Infectious diseases } & a) & Angina. \\
\hline & b) & Infection \\
\hline & $\begin{array}{r}\text { Bot } \\
\mathrm{cc}\end{array}$ & $\begin{array}{l}\text { Botulism (poisoning by canned or } \\
\text { cold cured meats). }\end{array}$ \\
\hline & d) & Diphtheria. \\
\hline & $\mathrm{N}$ & $\begin{array}{l}\text { Nephritis (inflammation of the } \\
\text { renal tissue). }\end{array}$ \\
\hline & $\begin{array}{l}\text { f) Goit } \\
\text { neck due to pa }\end{array}$ & $\begin{array}{l}\text { Goiter (thickness at the base of the } \\
\text { to pathology of the thyroid gland). }\end{array}$ \\
\hline \multirow{6}{*}{$\begin{array}{l}\text { Tumors or primary } \\
\text { or secondary } \\
\text { cancer }\end{array}$} & a) & Lipoma (fatty tumor), etc. \\
\hline & b) & Cancer: \\
\hline & i. & of the pharynx; \\
\hline & & of the esophagus; \\
\hline & \multicolumn{2}{|c|}{ iii. at the neck; } \\
\hline & \multicolumn{2}{|r|}{ at the head. } \\
\hline \multirow{4}{*}{$\begin{array}{l}\text { Disease of the } \\
\text { nervous or } \\
\text { muscular system }\end{array}$} & a) & Parkinson'sdisease. \\
\hline & \multicolumn{2}{|c|}{ b) Alzheimer's. } \\
\hline & c) & Cerebralpalsy. \\
\hline & \multicolumn{2}{|r|}{ myopathy. } \\
\hline
\end{tabular}




\begin{tabular}{|c|c|}
\hline \multirow{3}{*}{ Stroke } & The brain stem. \\
\hline & Bihémisphérique. \\
\hline & Hemorrhagic. \\
\hline \multirow{3}{*}{$\begin{array}{l}\text { Invasive or non- } \\
\text { invasive medical } \\
\text { treatment }\end{array}$} & $\begin{array}{l}\text { a) Surgical operation with nasogastric } \\
\text { intubation (placement of a tube in the nose and } \\
\text { throat during anesthesia). }\end{array}$ \\
\hline & $\begin{array}{l}\text { Radiotherapeutic treatment (use of } \\
\text { the rays as therapeutic). }\end{array}$ \\
\hline & Taking certain medications. \\
\hline
\end{tabular}

\section{Symptoms of dysphagia}

Symptoms of dysphagia are many:

a. Inability to swallow saliva;

b. Cough pre, per or post-deglutition;

c. A bolus (a mouthful) comes out through the lips;

d. Printing of food remaining glued into the pharynx;

e. Difficulty in swallowing a bite;

f. Feeling of blockage in the chest behind the sternum;

g. Changes in respiratory rhythm;

h. Dysphagia to solids and liquids

\section{Diagnosis of dysphagia}

It is necessary to distinguish between constant dysphagia linked to the swallowing of food (organic damage) and the difficulty of swallowing encountered in an anxious person. The diagnosis must also eliminate cancer of the aero-digestive tract. Here are the successive stages of the diagnosis of so-called esophageal dysphagia, in which the sensation of discomfort is situated in the thoracic cage (Table 2).

Table 2.

\begin{tabular}{|c|c|c|}
\hline \multicolumn{3}{|c|}{ Diagnosis of dysphagia } \\
\hline \multirow{12}{*}{$\begin{array}{l}\text { Step 1: } \\
\text { Search for items by } \\
\text { interrogation }\end{array}$} & a) & Whereis the embarrassment? \\
\hline & b) & $\begin{array}{l}\text { Does it occur with solids or } \\
\text { liquids? }\end{array}$ \\
\hline & c) & $\begin{array}{l}\text { How did the embarrassment start } \\
\text { (suddenly or gradually)? }\end{array}$ \\
\hline & d) & How has itevolved? \\
\hline & e) & $\begin{array}{l}\text { What is the general condition of } \\
\text { the person? }\end{array}$ \\
\hline & i. & Cognitive assessment? \\
\hline & ii. & Alcoholconsumption? \\
\hline & iii. & Is the person smoker? \\
\hline & iv. & Does she take medication? \\
\hline & $\mathrm{v}$. & Has she been exposed to irritants? \\
\hline & & $\begin{array}{l}\text { Are there any associated symptoms } \\
\text { esophageal reflux, hiccough, false } \\
\text { route)? }\end{array}$ \\
\hline & g) & Did the person lose abnormally? \\
\hline
\end{tabular}

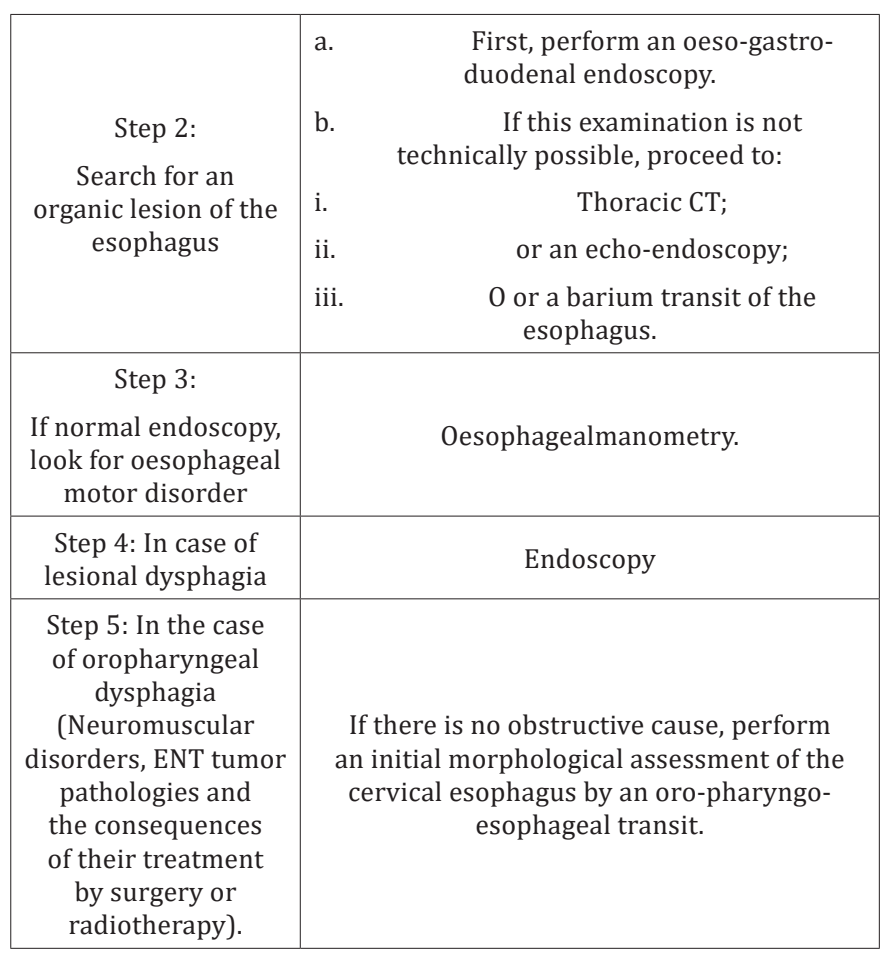

\section{Role of the speech therapist in dysphagia}

The speech-language pathologist is committed to maintaining autonomy and oral feeding as long as possible. Three criteria guide its action:

a. The recovery prognosis of the patient: can the person recover (cranial trauma, etc.) or should his condition worsen (Alzheimer's dementia, etc.)?

b. Physiopathological observations of the disease provided by functional exploration.

c. The general condition of the patient, as anxiety, fatigue, pulmonary congestion or depression can increase dysphagia.

The most common techniques to treat dysphagia in speech therapy are compensation and rehabilitation (Table 3).

Table 3.

\begin{tabular}{|c|c|}
\hline \multicolumn{2}{|c|}{ The most common techniques } \\
\hline $\begin{array}{l}\text { Technique of } \\
\text { compensation }\end{array}$ & $\begin{array}{c}\text { a)Development of compensatory techniques } \\
\text { (change the position of the head ...). } \\
\text { b)Do not treat dysphagia but allow the } \\
\text { person to eat. }\end{array}$ \\
\hline $\begin{array}{l}\text { Rehabilitation of } \\
\text { the muscles and } \\
\text { mechanisms of } \\
\text { swallowing }\end{array}$ & $\begin{array}{l}\text { a) } \begin{array}{l}\text { Physical training of muscles and } \\
\text { chewing structures. }\end{array} \\
\text { b) In a more or less long term and in } \\
\text { some cases, improved ability to swallow or } \\
\text { even disappear dysphagia. }\end{array}$ \\
\hline
\end{tabular}


Your next submission with Juniper Publishers will reach you the below assets

- Quality Editorial service

- Swift Peer Review

- Reprints availability

- E-prints Service

- Manuscript Podcast for convenient understanding

- Global attainment for your research

- Manuscript accessibility in different formats (Pdf, E-pub, Full Text, Audio)

- Unceasing customer service

Track the below URL for one-step submission https://juniperpublishers.com/online-submission.php 